\title{
PENGARUH BERBAGAI MACAM RANSUM KOMERSIAL DENGAN MENGGUNAKAN SISTEM KANDANG YANG BERBEDA TERHADAP KUALITAS KARKAS AYAM PEDAGING
}

\author{
Anggella T. Tombuku*, Vonny Rawung ${ }^{* *}$, Martina Montong ${ }^{* *}$, Zulkifli Poli** \\ Fakultas Peternakan Universitas Sam Ratulangi, Manado
}

\begin{abstract}
ABSTRAK
Penelitian ini bertujuan untuk mengetahui kualitas karkas ayam pedaging yang diberi 3 macam ransum komersial dengan menggunakan 2 sistem kandang yang berbeda. Ternak yang digunakan yaitu ayam pedaging umur 1 hari sebanyak 96 ekor dan per petakkan berisi 4 ekor. Penelitian dilakukan menggunakan Rancangan Acak Lengkap (RAL) dengan pola perlakuan 3x2 dengan 4 kali ulangan. Perlakuan yang diberikan yaitu Faktor $\mathrm{A}=3$ Macam Ransum ; $\mathrm{A} 1=$ Ransum Pokhpand (CP 11) ; A2 = Ransum Cargill (Avibro) ; A3 = Ransum Sierad (BSG 101) dan Faktor B = Sistem Kandang ; B1 = Kandang Baterai ; B2 = Kandang Litter. Hasil penelitian menunjukkan bahwa pengaruh berbagai macam ransum dengan menggunakan sistem kandang yang berbeda baik dalam perlakuan kombinasi maupun perlakuan tunggal memberikan pengaruh yang sama terhadap kualitas karkas ayam pedaging. Berdasarkan hasil dan penelitian dapat disimpulkan bahwa Pemberian berbagai macam ransum dengan menggunakan sistem kandang yang berbeda memberikan pengaruh yang sama terhadap persentase karkas, lemak abdomen ayam pedaging. Pemberian berbagai macam ransum memberikan pengaruh yang sama terhadap persentase karkas, lemak abdomen ayam pedaging. Sistem kandang yang berbeda memberikan pengaruh yang sama terhadap persentase karkas, lemak abdomen ayam pedaging. Sistem kandang litter dan umur pemotongan 6 minggu mengurangi resiko terjadinya lepuh dada.
\end{abstract}

Kata kunci : Ransum, kandang, ayam pedaging, kualitas karkas.

*) Alumni Fakultas peternakan

**) Jurusan Produksi Ternak Fakultas Peternakan Unsrat 


\begin{abstract}
THE EFFECT OF VARIOUS COMMERCIAL RATIONS COMBINED WITH DIFFERENT CAGE SYSTEM ON CARCASS QUALITY OF BROILERS. The objective of this research was to determine carcass quality of broilers fed with three forms of commercial ration using 2 different cages. Total of 96 day old chicks were used in this study using four animals in each cage. Research was conducted using a completely randomized design divided into $3 \times 2$ patterns of treatment with 4 replications. Three forms of commercial ration (Factor A) consisted of A1 = Pokhpand Ration (CP 11 ); A2 = Cargill Ration (Avibro) and $\mathrm{A} 3=$ Sierad Ration (BSG 101). Two different cages (Factor B) consisted of B1 = Battery Cage $; \mathrm{B} 2=$ Litter System. The results showed that three forms of commercial ration combined with two different cage systems give the same effect on carcass quality of broilers in terms of carcass percentage and abdominal fat weight. Litter system and animal slaughter at 6 weeks of age reduced the risk of breast blisters.
\end{abstract}

Keywords: Rations, cage, broiler, carcass quality.

\title{
PENDAHULUAN
}

Ayam pedaging (broiler) adalah salah satu jenis ternak yang memberikan kontribusi cukup besar dalam memenuhi kebutuhan protein asal hewan bagi masyarakat Indonesia. Setiap tahunnya kebutuhan masyarakat akan daging broiler terus meningkat. Peningkatan ini terjadi karena daging broiler harganya terjangkau oleh semua kalangan masyarakat. Ayam broiler adalah jenis ternak unggas yang memiliki laju pertumbuhan yang sangat cepat, pada umur 5-6 minggu ayam broiler sudah bisa dipanen. Pada pemeliharaan ayam pedaging factor yang penting diperhatikan diantaranya pakan dan kandang, karena biaya pakan merupakan biaya produksi terbesar dan merupakan kebutuhan mutlak yang harus dipenuhi untuk pertumbuhan ayam pedaging. Sedangkan kandang dibutuhkan sebagai tempat hidup dari awal (DOC) sampai periode panen.

Ransum komersial merupakan gabungan dari beberapa bahan yang disusun sedemikian rupa dengan formulasi tertentu yang sudah dihitung (dikalkulasi) sebelumnya berdasarkan kebutuhan industri dan energi yang diperlukan untuk memenuhi kebutuhan ternak. Ransum dinyatakan berkualitas baik apabila mampu memberikan seluruh nutrien secara tepat, baik jenis, jumlah, serta imbangan nutrien tersebut bagi ternak. Ransum komersial mengandung zat-zat makanan seperti : protein, kabohidrat, lemak, mineral, vitamin, yang dibutuhkan oleh ayam pedaging. Biasanya peternak mendapatkan dari perusahaan-perusahaan makanan ternak seperti PT. Charoen Pokphand, PT. Cargill, dan PT. Sierad Produce Tbk. Ketiga ransum ini merupakan ransum yang saat ini banyak diminati masyarakat. Setiap perusahaan masing-masing memiliki keistimewaan yang merupakan rahasia dari perusahaan tersebut.

Sistem perkandangan ayam broiler yang sering digunakan yaitu sistem baterai dan sistem litter. Pemeliharaan ayam broiler pada sistem kandang litter dan baterai 
memberikan keuntungan dan kerugian. Keuntungan pemeliharaan pada sistem baterai memudahkan pengontrolan penyakit, kotoran mudah dibuang sehingga penyebaran penyakit lebih sedikit. Sedangkan kerugian pemeliharaan ayam broiler pada sistem baterai yaitu mudah menimbulkan breast blister (lepuh dada), persentase lemak abdomennya tinggi akibat ayam sedikit bergerak atau tidak memiliki aktifitas seperti pada kandang litter yaitu mengais-ngais litter.

Keuntungan pada kandang sistem litter yaitu litter yang mengalami dekomposisi menjadi sumber nutrien tambahan (vitamin, mineral, dan protein), proses mengais litter memberikan manfaat pada sistem pencernaan karena ayam akan lebih cepat memproses makanan karena pada sitem kandang ini alasnya terdiri dari sekam padi, kapur dan pasir yang dapat membantu tembolok ayam dalam memproses makanan, bahan-bahan litter bersifat menyerap air. Sedangkan kerugian pada kandang sistem litter yaitu mudah terjangkit penyakit dan akan menurunkan konsumsi ransum yang dapat mempengaruhi berat karkas.

Dewasa ini industri broiler dituntut untuk menghasilkan daging rendah lemak, karena lemak mempunyai pengaruh negative terhadap kesehatan konsumen. Kandungan lemak yang paling banyak adalah di daerah perut, dan inilah yang menyebabkan kualitas karkas menjadi rendah, serta mempunyai nilai jual yang rendah pula. Menurut Suprijatna dan Kartasudjana (2005), ayam akan mengkonsumsi ransum untuk memenuhi kebutuhan energinya, sebelum kebutuhan energinya terpenuhi ayam akan terus makan. Jika ayam diberi makan dengan kandungan energi rendah maka ayam akan makan lebih banyak, dibandingkan ransum dengan kandungan energi tinggi, maka semakin rendah konsumsi ransumnya, karena ayam makan untuk memenuhi kebutuhan energinya selanjutnya dinyatakan bahwa kelebihan energi dapat diubah menjadi lemak tubuh. Dalam Parakkasi (1995) bila energi dalam bahan makanan berlebihan dari metabolisme normal maka akan terjadi penimbunan lemak, salah satu tempat penimbunan lemak ini terbentuk di daerah abdomen.

\section{MATERI DAN METODE PENELITIAN}

Penelitian ini dilaksanakan dikandang Percobaan Laboratorium Unggas Jurusan Produksi Fakultas Peternakan Universitas Sam Ratulangi. Ternak yang akan digunakan dalam penelitian ini yaitu ayam pedaging strain $\mathrm{CP} 707$ umur 1 hari sebanyak 96 ekor yang secara acak dibagi dalam 3 perlakuan ransum dan 4 kali ulangan dan setiap ulangan terdiri dari 4 ekor ayam pedaging. Perlakuan menggunakan ransum komersil dari 3 perusahaan yang berbeda yaitu PT. Charoen Pokhpan, PT. Cargill Indonesia, PT. Sierad Produce Tbk dan menggunakan 12 unit kandang baterai, 12 unit kandang litter yang sama-sama berukuran $60 \times 45 \times 45$ $\mathrm{cm}$. Kandang dilengkapi dengan tempat makan dan tempat minum yang diletakan didalam kandang. Unit kandang ditempatkan didalam ruangan dengan ventilasi dan cahaya yang cukup. Peralatan lain yang digunakan adalah kantong plastik, ember, sapu, termometer, timbangan digital, lampu pijar, sekam padi, pasir, kapur, triples, pisau dan koran bekas. Peralatan yang digunakan dalam analisis kualitas karkas yaitu pisau, ember, panci untuk pemanasan, timbangan digital, alat tulis, mistar penggaris, dan peralatan lain yang menunjang kegiatan penelitian. Perlakuan yang diberikan adalah sebagai berikut : 
Faktor A : 3 Macam Ransum Komersil

A1 = Ransum Pokhpand (CP 11)

$\mathrm{A} 2=$ Ransum Cargill (Avibro)

A3 = Ransum Sierad (BSG 101)

Faktor B : 2 Sistem Kandang

B1 = Kandang Baterai

B2 = Kandang Litter

\section{Variabel Penelitian}

- Persentase Karkas : Diperoleh dari hasil perbandingan antara berat karkas (gram) dengan berat hidup (gram) dikalikan 100\% (Nort, 1990)

- Lemak Abdomen : Diperoleh dari hasil perbandingan antara berat lemak abdomen (gram) dengan berat hidup (gram) dikalikan 100\% (Witantra, 2011)

- Lepuh Dada : Dengan melihat persentase ayam yang mengalami lepuh dada yang dipelihara dikandang sistem litter dan kandang sistem baterai.

\section{Analisis Data}

Data yang diperoleh dari analisis ini ditabulasi dan dianalisa dengan menggunakan ANOVA sesuai dengan rancangan yang digunakan yaitu Rancangan Acak Lengkap (RAL) dengan pola perlakuan Faktorial 3x2 dan 4 kali ulangan.

\section{HASIL DAN PEMBAHASAN}

\section{Pengaruh Perlakuan Terhadap Persentase Karkas}

Data hasil pengamatan untuk pengaruh berbagai macam ransum dengan sistem kandang yang berbeda terhadap persentase karkas tercantum pada Tabel 1, menunjukkan rataan persentase karkas perlakuan kombinasi berbagai macam ransum dengan sistem kandang yang berbeda persentase tertinggi pada perlakuan kombinasi A1B1 81,83\% dan terendah pada perlakuan kombinasi A2B1 76,24\%. Pada perlakuan berbagai macam ransum yang tertinggi pada A1 terendah pada A2 dan pada perlakuan sistem kandang tertinggi pada B1 terendah pada B2.

Hasil analisa keragaman menunjukan kombinasi perlakuan berbagai macam ransum dengan sistem kandang yang berbeda memberikan pengaruh yang tidak nyata $(\mathrm{P}>0,05)$ terhadap persentase karkas. Hal yang sama ditunjukan oleh pengaruh pemberian berbagai macam ransum (Faktor A) menunjukan pengaruh yang tidak nyata. Demikian juga pada sistem kandang (Faktor B) memberikan pengaruh yang tidak nyata. Hasil yang tidak nyata dalam analisa keragaman menunjukan bahwa perlakuan berbagai macam ransum dengan sistem kandang yang berbeda baik dalam perlakuan kombinasi maupun perlakuan tunggal tidak memberikan pengaruh terhadap persentase karkas. Hal ini disebabkan karena kandungan zat-zat makanan dari ketiga ransum khususnya protein yang berfungsi sebagai bahan pembentuk jaringan dalam penelitian ini masih sesuai dengan standar kebutuhan sesuai yang direkomendasikan oleh Suprijatna dan 
Kartasudjana (2005) kebutuhan protein untuk ayam broiler 20-23 g/ekor/hari, selanjutnya Yamin (2002) Pakan harus mengandung zat nutrisi dalam keadaan cukup dan seimbang sehingga dapat menunjang pertumbuhan maksimal dan menghasilkan bobot akhir yang tinggi. Menurut Indarto (2010) untuk mencapai pertumbuhan yang baik dalam produksi ayam pedaging, ransum yang diberikan harus sempurna dan mencukupi dalam arti ransum yang diberikan harus mengandung semua zat-zat makanan yang diperlukan oleh tubuh dengan kualitas yang baik dalam jumlah yang sesuai dengan kebutuhan. Demikian juga dengan sistem kandang (Faktor B) yang tidak memberikan pengaruh yaitu karena luasan kandang yang digunakan dalam penelitian ini ukurannya sama baik untuk sistem litter maupun bateray sehingga memungkinkan pergerakkannya adalah sama.

Persentase karkas dari masing-masing perlakuan (tabel 1) $77-80 \%$ lebih tinggi dari yang dilaporkan North (1990) bahwa persentase karkas "Ready to Cook" adalah 70-77\% dari berat hidupnya. Selanjutnya, Murtidjo (2003) menyatakan rataan berat karkas ayam pedaging berkisar antara $65-75 \%$ dari berat hidup pada waktu siap dipotong. Soeparno (1994), menyatakan faktor yang mempengaruhi karkas adalah bangsa, jenis kelamin, umur, berat tubuh, dan makanan. Umur berpengaruh terhadap berat karkas yang disebabkan oleh adanya perubahan alat-alat tubuh terutama penambahan dari lemak karkas. Murtidjo (2003), menyatakan cara pemeliharaan juga mempunyai kaitan dengan kualitas persentase karkas broiler.

\subsection{Pengaruh Perlakuan Terhadap Persentase Lemak Abdomen}

Hasil pengukuran dan perhitungan rataan persentase lemak abdomen dari setiap perlakuan selama percobaan tercantum pada Tabel 2, menunjukan bahwa rataan persentase lemak abdomen pengaruh kombinasi berbagai macam ransum dengan sistem kandang berkisar antara 1,54\% - 1,83\% perlakuan kombinasi tertinggi yaitu pada A3B1 1,83\% dan terendah pada A1B2 1,54\%. Secara keseluruhan persentase tertinggi yaitu pada kandang sistem bateray sekitar 1,69 $\%$. Pada faktor berbagai macam ransum tertinggi A3 terendah pada A1 dan untuk sistem kandang persentase tertinggi pada B1 terendah pada B2.

Hasil analisa keragaman menunjukan bahwa perlakuan kombinasi pemberian berbagai macam ransum dengan sistem kandang yang berbeda memberikan pengaruh tidak nyata $(\mathrm{P}>0,05)$ terhadap persentase lemak abdomen. Hal yang sama ditunjukan oleh pengaruh pemberian berbagai macam ransum (Faktor A) menunjukan pengaruh yang tidak nyata. Demikian juga pada sistem kandang (Faktor B) memberikan pengaruh yang tidak nyata. Hasil yang tidak nyata dalam analisa keragaman menunjukan bahwa perlakuan berbagai macam ransum dengan sistem kandang yang berbeda baik dalam perlakuan kombinasi maupun perlakuan tunggal tidak memberikan pengaruh terhadap persentase lemak abdomen. Hal ini disebabkan energi dalam ransum yang digunakan pada penelitian ini masih sesuai dengan standar kebutuhan energi ayam pedaging yaitu 2800-3300 kkal/kg (Rasyaf, 2009). Selanjutnya, Dalton dan Lot (1985) menyatakan bahwa persentase lemak abdomen meningkat dengan bertambahnya umur dan tingkat energi ransum. Kelebihan energi dalam tubuh ayam akan disimpan dalam bentuk lemak, sedangkan metabolisme pembentukan lemak 
tersebut membutuhkan banyak energi, maka secara tidak langsung terjadi pemborosan energi ransum sehingga terjadi pengurangan kualitas karkas. Apabila ternak kekurangan energi, maka cadangan energi dalam tubuh akan digunakan sebaliknya kelebihan energi dalam ransum akan menimbulkan perlemakan yang tinggi sehingga menurunkan kualitas karkas. Demikian juga dengan sistem kandang (Faktor B) yang digunakan disebabkan luasan kandang adalah sama sehingga penggunaan energi untuk aktifitasnya adalah sama. Selain itu imbangan protein energi ransum yang diberikan relatif sama seperti yang direkomendasikan oleh Scott et al. (1982) kebutuhan energi metabolis ayam tipe ringan umur 2-8 minggu sebesar $2600-3100 \mathrm{kkal} / \mathrm{kg}$ dan protein pakan antara $18 \%$ - 24\%. Selanjutnya, Widjastuti T dan Garnida D (2011) ransum dengan kandungan energi protein tinggi mengakibatkan kebutuhan energi akan cepat terpenuhi sehingga penimbunan lemak abdominal relatif rendah.

Persentase lemak abdomen dari masing-masing perlakuan (Tabel 3) 1,57$1,73 \%$ masih sesuai dengan batasan persentase lemak abdomen yang dinyatakan oleh Maffudz (2009), persentase lemak abdomen rata-rata sebesar 1,92\% atau berkisar antara 0,73-3,78\%. Sedangkan menurut hasil penelitian Pratikno (2011) rata-rata lemak abdomen ayam pedaging yang dipelihara selama 6 minggu berkisar antara 2,49-2,50\% dari bobot badan ayam pedaging. Lemak abdomen merupakan salah satu komponen lemak tubuh, yang terdapat dalam rongga perut. Lemak abdomen merupakan indikator terhadap lemak karkas, turunnya lemak abdomen menyebabkan lemak karkas juga turun (Becker dkk, 1981) kemudian dinyatakan bahwa lemak abdomen dapat dipergunakan untuk menghitung lemak karkas atau lemak tubuh secara keseluruhan. Lemak abdomen dan lemak karkas mempunyai hubungan korelasi positif, yaitu ketika lemak abdomen meningkat maka lemak karkas juga meningkat.

\subsection{Pengaruh Perlakuan Terhadap Lepuh Dada}

Pengaruh perlakuan terhadap lepuh dada pada karkas ayam broiler dari setiap perlakuan selama percobaan tercantum pada Tabel 4, menunjukkan bahwa ayam yang mengalami lepuh dada hanya terjadi pada perlakuan kombinasi ransum A1 dengan sistem kandang bateray B1 dan ransum A2 pada sistem kandang bateray B1. Hasil pengamatan menunjukkan ayam yang mengalami lepuh dada hanya terjadi pada perlakuan A1B1 sejumlah 1 ekor $(6,25 \%)$ dengan luas area lepuh $7,5 \times 4 \mathrm{~cm}$ dan pada perlakuan kombinasi A2B1 sejumlah 1 ekor $(6,25 \%)$ dengan luas area lepuh lepuh $8 \times 6 \mathrm{~cm}$. Sedangkan pada perlakuan kombinasi A3B1, A1B2, A2B2, dan A3B2 tidak terjadi lepuh dada. Hal ini sejalan dengan pendapat Rasyaf (2009) penggunaan alas litter memungkinkan tidak terjadinya lepuh dada, serta kepadatan dalam kandang juga mempengaruhi terjadinya lepuh dada. Selanjutnya, menurut Murtidjo (2003) cara pemeliharaan berkaitan dengan kualitas karkas ayam pedaging, ayam pedaging yang dipelihara pada kandang sistem litter akan memiliki karkas yang baik, sebaliknya jika dipelihara di kandang sistem bateray sering menderita memar dada sehingga kualitasnya berkurang. Penggunaan sistem alas litter memungkinkan terjadinya lepuh dada lebih rendah dibandingkan dengan sistem alas bateray sehingga kualitas karkasnya lebih baik. 
Pada penelitian ini ayam dipanen pada umur 6 minggu sehingga luas kandang litter maupun bateray masih cukup luas untuk pergerakan ayam broiler. Menurut Sinurat et al.,(1995) umur 5-6 minggu merupakan waktu yang tepat untuk dipanen dari segi cacat karkas karena menjadi salah satu penyebab terjadinya lepuh dada, semakin meningkatnya umur ayam bobot ayam semakin tinggi sehingga ayam akan lebih banyak duduk karena kakinya tidak bisa menopang berat tubuh yang dapat mengakibatkan terjadinya lepuh dada.

\section{KESIMPULAN}

1. Pemberian berbagai macam ransum dengan menggunakan sistem kandang yang berbeda memberikan pengaruh yang sama terhadap persentase karkas, lemak abdomen ayam pedaging.

2. Pemberian berbagai macam ransum memberikan pengaruh yang sama terhadap persentase karkas, lemak abdomen ayam pedaging.

3. Sistem kandang yang berbeda memberikan pengaruh yang sam terhadap persentase karkas, lemak abdomen ayam pedaging.

\section{DAFTAR PUSTAKA}

Becker W.A., 1981. Abdominal and Carcars Fat in Five Broiler Strains Doult.

Dalton, J.W,and B.D. Lott. 1985. Age and Dietary Energy Effect on Broiler Abdominal Fat Deposition.

Indarto, N. 2010. Sukses dan Untung Besar Beternak Ayam Broiler. Lumine Books. Yogyakarta

Maffudz, 2009. Karkas dan Lemak Abdominal Ayam Broiler yang Diberi Ampas Bir dalam Ransum. //http://aPNR3-(28)_lufti-2-seting.pdf//.[Tanggal Akses : 14 Maret 2011].

Murtidjo, B A.2003. Pedoman Beternak Ayam Broiler. Kanisius. Yogyakarta.

North, M.O. 1990. Commercial chicken production manual. $5^{\text {rd }}$ edition. Company Publishing. Inc. Websport, Connecticut.

Parakkasi A., 1995. Ilmu Gizi dan Makanan Ternak Monogastrik. Fakultas Peternakan IPB. Penerbit Angkasa. Bandung.

Pratikno, H. 2011. Lemak Abdominal Ayam Broiler (Gallus sp.) karena Pengaruh Ekstrak Kunyit(Curcuma domestica.). Journal BIOMA. Vol. 13, No. 1.

Rasyaf, M. 2009. Panduan Beternak Ayam Pedaging. Penebar Swadaya : Depok.

Scott, M.L.,M.C. Nesheim and R. J. Young, 1982. Nutrition of the Chickens. Second Ed. M.L. Scott and Associates Ithaca,New York. 
Sinurat, A. P., D. Zainuddin dan R. Dharsono. 1995. Pengujian Penampilan Biologi Ayam Pedaging Strain Hybro pada Lantai Litter dan Kawat. Ilmu dan Peternakan.

Steel, R. G. D. , J. H. Torrie. 1995. Principles and procedure of statistics. Mc Graw-Hill International Book Co. Tosho Printing Co. Ltd. Tokyo Japan

Suprijatna, E., U. Atmomarsono dan R. Kartasudjana. 2005. Ilmu Dasar Ternak Unggas. Penebar Swadaya, Jakarta.

Soeparno. 1994. Tekhnologi Pengawasan Daging. Institute Pertanian Bogor

Widjastuti, T. dan Garnida, D. 2011. Evaluasi performans ayam merawang phase Pertumbuhan 12 minggu pada kandang sistem Kawat dan sistem litter dengan berbagai Imbangan energi - protein didalam ransum. Fakultas Peternakan Universitas Padjadjaran Jatinangor, Sumedang 45363.

Witantra. 2011. Pengaruh Pemberian Lisin dan Metionin Terhadap Persentase Karkas dan Lemak Abdominal pada AyamPedaging Asal Induk Bibit Mudadan Induk Bibit Tua. Artikel Ilmiah. Universitas Airlangga. Surabaya.

Yamin, M. 2002. Pengaruh Tingkat Protein Pakan terhadap Konsumsi, Pertambahan Bobot Badan dan IOFC Ayam Buras Umur 0-8 Minggu. Jurnal Agroland Vol. 9 No. 3 September 2002. 
Tabel 1. Rataan persentase pengaruh berbagai macam ransum dengan sistem kandang yang berbeda terhadap karkas ayam pedaging

\begin{tabular}{ccccc}
\hline \multirow{2}{*}{ Kandang } & \multicolumn{3}{c}{ Ransum } & \multirow{2}{*}{ Rataan } \\
\cline { 2 - 4 } B1 & $\mathbf{8 1 , 8 3}$ & $\mathbf{7 6 , 2 4}$ & $\mathbf{7 9 , 8 7}$ & $\mathbf{7 9 , 3 1}$ \\
B2 & $\mathbf{7 9 , 7 9}$ & $\mathbf{7 8 , 9 3}$ & $\mathbf{8 0 , 7 7}$ & $\mathbf{7 9 , 8 3}$ \\
\hline Rataan & $\mathbf{8 0 , 8 1}$ & $\mathbf{7 7 , 5 8}$ & $\mathbf{8 0 , 3 2}$ & $\mathbf{7 9 , 5 7}$ \\
\hline
\end{tabular}

Tabel 2. Rataan persentase pengaruh berbagai macam ransum dengan sistem kandang yang berbeda terhadap lemak abdomen ayam pedaging

\begin{tabular}{crrrr}
\hline & \multicolumn{3}{c}{ Ransum } & \\
\cline { 2 - 4 } Kandang & $\mathbf{A 1}$ & $\mathbf{A 2}$ & $\mathbf{A 3}$ & Rataan \\
\hline B1 & 1,61 & 1,62 & 1,83 & 1,69 \\
B2 & 1,54 & 1,64 & 1,62 & 1,60 \\
\hline Rataan & 1,57 & 1,63 & 1,73 & 1,64 \\
\hline
\end{tabular}

Tabel 3. Persentase pengaruh berbagai macam ransum dengan sistem kandang yang berbeda terhadap lepuh dada ayam pedaging

\begin{tabular}{cccc}
\hline & \multicolumn{3}{c}{ Ransum } \\
\cline { 2 - 4 } Kandang & A1 & A2 & A3 \\
\hline B1 & 6,25 & 6,25 & 0 \\
B2 & 0 & 0 & 0 \\
\hline
\end{tabular}

